(С Дем’янишин В. М., Медвідь Ю. І., 2017

Дем'янишин Володимир Миколайович, Медвідь Юлія Іванівна

Національна академія Національної гвардії України

\title{
ПРОФЕСІЙНЕ САМОВИЗНАЧЕННЯ ГРОМАДЯНИНА УКРАЇНИ ЩОДО ПРОХОДЖЕННЯ ВІЙСЬКОВОЇ СЛУЖБИ ЗА КОНТРАКТОМ ЯК НАУКОВО-ПЕДАГОГІЧНА ПРОБЛЕМА
}

Виявлено існування практичної проблеми дослідження, яка проявляється у зміні способу комплектування військових формувань 3 призовного на контрактний, щзо призводить до зникнення найбільш значущих умов формування у громадян Украйни готовності до проходження військової служби за контрактом. Відповідно виявлено існування науково-педагогічної проблеми професійного самовизначення старшокласників щэодо проходження військової служби за контрактом, яка проявляється у відсутності досліджень присвячених вирішенню практичної проблеми шляхом сумісного виконання завдань загальноосвітніх шкіл щодо сформованості у їхніх випускників готовності до вибору професії та військових формувань щодо зміни їх способу комплектування на контрактний. Розкрито сутність поняття «професійне самовизначення старшокласника щодо проходження військової служби за контрактом» під яким запропоновано розуміти розгорнутий в часі процес самостійного узгодження досягнутих але ще не реалізованих ним можливостей $i$ вимог проходження військової служби за контрактом щодо стану здоров'я та психологічного стану.

Ключові слова: професійне самовизначення, військова служба за контрактом.

Проблема, її зв'язок із важливими науковими чи практичними завданнями. У 2002 році розпочато реформування військових формувань та правоохоронних органів спеціального призначення шляхом зміни способу їх комплектування з призовного на контрактний. Проте завершити цей процес вдалося лише Службі безпеки України (у 2007 році) та Державній прикордонній службі України (у 2008 році) [1, с. 1]. Основна частина військовослужбовців, які вперше укладають контракт, - це ті, хто залишився служити після строкової служби. Якщо перехід військових формувань та правоохоронних органів спеціального призначення на контрактний 
спосіб комплектування завершиться (буде скасовано призов на строкову службу), а умови, в яких проходитиме цей процес, залишаться незмінними, то стан комплектування військових посад погіршиться, а відповідно й ефективність виконання службовобойових завдань знизиться. Адже спілкуючись у колективі, військовослужбовець строкової служби може дізнатися про умови проходження служби військовослужбовцем-контрактником, про перспективи подальшої служби, тобто має змогу отримати всю необхідну інформацію для прийняття позитивного рішення щодо укладення контракту про проходження військової служби. Певна річ, інші люди такої можливості не мають. Через засоби масової інформації можна поширити загальну інформацію про привабливість військової професії та про її нематеріальні сторони - такі, як служіння Вітчизні, честь, відданість. Для докладного ж роз'яснення всього комплексу матеріальних пільг, кар'єрних перспектив та освітніх програм треба працювати індивідуально 3 кожним потенційним кандидатом. Отже, з припиненням існування призовного способу комплектування зникнуть і найбільш значущі умови формування у особистості готовності до проходження військової служби за контрактом. У цьому і проявляється практична проблема. На думку авторів роботи зазначену проблему доцільно вирішувати у загальноосвітніх навчальних закладах через професійне самовизначення старшокласників щодо проходження військової служби за контрактом. Науково-педагогічна проблема буде проявлятись у відсутності наукових праць направлених на вирішення зазначеної практичної проблеми.

Аналіз публікацій (виділення невирішених проблем). Щоб переконатись у існуванні чи відсутності науково-педагогічної проблеми нами здійснено аналіз положень наукової новизни дисертацій та монографій за темою дослідження (табл. 1).

За результатами аналізу виявлено відсутність наукових праць присвячених вирішенню практичної проблеми професійного самовизначення старшокласників щодо проходження військової служби за контрактом. Комплексні дослідження 3 професійного самовизначення учнів здійснили такі учені як О. І. Вітковська [12], Л. І. Гриценок [11], Л. А. Гуцан [11], Д. О. Закатков [10], О. В. Капустіна [6], $\quad$ Г. О. Корсун [13], $\quad$ В. Т. Лозовецька [3], В. В. Мачуський [3],

А. А. Назарчук [8],

О. Ю. Пащенко [2],

О. В. Мельник [5],

3. В. Охріменко [11],

М. І. Піддячий [4],

О. Л. Морін [11],

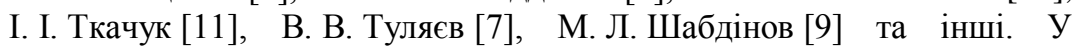
більшості згаданих досліджень розглядались поняттєво-категоріальний апарат, принципи, форми та методи професійного самовизначення 


\section{Збірник наукових статей}

учнів, педагогічні умови формування готовності до професійного самовизначення, визначення їх критеріїв, показників та рівнів готовності. Проте, що собою представляє «професійне самовизначення старшокласників щодо проходження військової служби за контрактом» у наукових працях не визначено.

Таблиия 1

Аналіз положень наукової новизни

дисертацій та монографій за темою дослідження

\begin{tabular}{|c|c|c|c|c|}
\hline Учений, наукова праця & $\begin{array}{c}\text { Поняттєво- } \\
\text { категоріальний } \\
\text { апарат }\end{array}$ & $\begin{array}{l}\text { Принципи, } \\
\text { форми та } \\
\text { методи }\end{array}$ & $\begin{array}{c}\text { Педагогічні } \\
\text { умови }\end{array}$ & $\begin{array}{c}\text { Критерії, } \\
\text { показники } \\
\text { та рівні } \\
\text { готовності }\end{array}$ \\
\hline О. Ю. Пащенко, 2000 [2] & & + & & + \\
\hline В. В. Мачуський, 2001 [3] & + & & & + \\
\hline М. І. Піддячий, 2002 [4] & + & & + & + \\
\hline О. В. Мельник, 2003 [5] & + & + & & + \\
\hline О.В.Капустіна, 2004 [6] & + & + & + & + \\
\hline В. В. Туляєв, 2008 [7] & + & & + & + \\
\hline А. А. Назарчук, 2009 [8] & + & + & + & + \\
\hline М. Л. Шабдінов, 2010 [9] & + & + & + & + \\
\hline Д. О. Закатков, 2012 [10] & + & + & & + \\
\hline $\begin{array}{l}\text { Л. А. Гуцан, О. Л. Морін та } \\
\text { ін., } 2016 \text { [11] }\end{array}$ & + & + & + & + \\
\hline
\end{tabular}

Ціль статті визначити сутність професійного самовизначення старшокласників щодо проходження військової служби за контрактом.

Виклад основного матеріалу, обгрунтування результатів дослідження. Розглянемо сутність професійного самовизначення старшокласників щодо проходження військової служби за контрактом. Самовизначення, на думку О. І. Вітковської, $є$ «свідома внутрішня діяльність особистості, спрямована на усвідомлення своїх життєвих цінностей і смислів, виходячи 3 чого молода людина визначає свою життєву позицію і стиль життя, своє місце у світі, серед людей. Центральною ланкою процесів самовизначення виступає вибір як свідома активність особистості і моральний вчинок. В основі здійснення вибору знаходиться процес розв'язання внутрішніх i зовнішніх протиріч» [12, с. 15]. Погоджуюсь з ученою і хочу додати, що на практиці не кожен учень готовий до професійного самовизначення - часто зустрічаємось $з$ тим, що визначення щодо вибору професії $\epsilon$ не школяра, а його батьків, рідних.

Аналізуючи наукові праці, зустрічаємо низку трактувань поняття «професійне самовизначення» (табл. 2). Враховуючи їх різноманітність необхідно звернутись до поняття «професія», яка в 
економічній енциклопедії трактується як «офіційно визнаний усталений і відносно самостійний вид трудової діяльності в системі суспільного поділу праці; комплекс об'єднаних загальною назвою теоретичних знань, умінь і трудових навичок, набутих у процесі навчання в спеціальних навчальних закладах і під час практичної роботи». Дане поняття розглядають у різних аспектах: 1) як конкретний вид суспільної організації праці; 2) як систему нормативних вимог до людини з боку певного роду діяльності; 3) як форму об'єднання групової спільноти; 4) як суспільну форму діяльності $[15$, с. 140]. Таким чином у понятті «професійне самовизначення» необхідним враховувати вимоги до професії. Зазначений підхід витриманий у визначені, яке запропоновано та використовується ученими Інституту проблем виховання НАПН України та яке ми будемо використовувати у нашому досліджені, а саме: «професійне самовизначення $є$ розгорнутим в часі процесом самостійного узгодження досягнутих але ще не реалізованих ним можливостей i вимог обраної або ж бажаної професії» $[9$, с. 12 ; 11, c. 12].

Процес професійного самовизначення, на думку Д.О. Закаткова, не може бути обмежений лише якимось одним етапом, він займає увесь період активної трудової діяльності людини й підготовки до неї [10, с. 34]. Іншої думки учені Інституту проблем виховання НАПН України. Вони вважають, що професійне самовизначення особистості містить допрофесійний i професійний періоди. Допрофесійний період охоплює пропедевтичний (діти до 14 років) і базовий (рання юність, підлітки від 15 до 17 років) етапи. Професійний період складається 3 адаптаційного (старший юнацький вік, молоді люди від 18 до 25 років) і фахового (молоді люди від 26 до 35 років) етапів [11, с. 25]. У дослідженні О. Д. Джури виокремлено декілька етапів професійне самовизначення в системі навчальновиховної роботи, зокрема, «початковий пов'язаний 3 емоційнообразним сприйняттям, характерним для дітей дошкільного віку, пропедевтичним (1-4 класи), пошукової спрямованості, на якому у підлітків виникають професійні наміри, період розвитку професійної самосвідомості, коли у школярів з'являється особистісний смисл вибору професії та уточнення соціально-професійного статусу (9-11 класи)» [16, с. 5]. Враховуючи, практичну проблему нашого дослідження ми обмежимося базовим етапом допрофесійного періоду професійного самовизначення особистості, що відповідає меті трудового виховання у старшій школі - «формування в учнів готовності до свідомого професійного самовизначення та моральнопсихологічна підготовка до майбутньої професійної діяльності» [17]. 
Трактування поняття «професійного самовизначення»

\begin{tabular}{|c|c|c|}
\hline $\begin{array}{c}\text { Пop. } \\
\text { № }\end{array}$ & $\begin{array}{c}\text { Автор та посилання } \\
\text { на джерело }\end{array}$ & Визначення «професійного самовизначення» \\
\hline 1. & $\begin{array}{l}\text { О. В. Мельник } \\
{[5, \text { с. } 16,17]}\end{array}$ & $\begin{array}{l}\text { «це діяльність, в основі якої лежить механізм } \\
\text { узгодження об'єктивних умов та суб'єктивних } \\
\text { факторів вибору, головним змістом якого є процес } \\
\text { підготовки і прийняття рішення на мотиваційно- } \\
\text { особистісному рівні» }\end{array}$ \\
\hline 2. & $\begin{array}{l}\text { О. В. Капустіна } \\
{[6, \text { с. } 13]}\end{array}$ & $\begin{array}{l}\text { «складне структурне утворення особистості, яке } \\
\text { відображає погляд людини на світ професій, на } \\
\text { конкретну професію, а також власні наміри щодо } \\
\text { самореалізації в рамках певної трудової діяльності» }\end{array}$ \\
\hline 3. & $\begin{array}{l}\text { М. Л. Шабдінов } \\
\text { [9. с. 12]; } \\
\text { Л. А. Гуцан, } \\
\text { О. Л. Морін, } \\
\text { 3. В. Охріменко, } \\
\text { О. М. Пархоменко, } \\
\text { Л. І. Гриценок, } \\
\text { І. І. Ткачук [11, с. 12] }\end{array}$ & $\begin{array}{l}\text { «€ розгорнутим в часі процесом самостійного } \\
\text { узгодження досягнутих але ще не реалізованих ним } \\
\text { можливостей і вимог обраної або ж бажаної } \\
\text { професії» }\end{array}$ \\
\hline 4. & $\begin{array}{l}\text { Д. О. Закатков } \\
{[10, \text { с. } 34]}\end{array}$ & $\begin{array}{l}\text { «процес самореалізації особистості в професійній } \\
\text { діяльності на основі найбільш повного } \\
\text { використання своїх й індивідуально-психологічних } \\
\text { можливостей» }\end{array}$ \\
\hline 5. & $\begin{array}{l}\text { О. І. Вітковська } \\
{[12, \text { с. } 16]}\end{array}$ & $\begin{array}{l}\text { «цілісний, інтегративний процес, у якому } \\
\text { реалізуються основні життєві цінності людини і } \\
\text { конкретизуються аспекти їі життєвого, } \\
\text { особистісного, соціального самовизначення; вибір } \\
\text { молодою людиною напряму і змісту свого } \\
\text { подальшого розвитку, сфери і засобів реалізації } \\
\text { індивідуальних якостей і здібностей, соціального } \\
\text { середовища для втілення своєї життєвої мети і } \\
\text { моральних цінностей» }\end{array}$ \\
\hline 6. & $\begin{array}{l}\text { С. М. Сошенко } \\
{[14, \text { с. } 3]}\end{array}$ & $\begin{array}{l}\text { «процес формування ставлення до себе як суб’єкта } \\
\text { майбутньої професійної діяльності, що } \\
\text { зумовлюється його індивідуальними особливостями } \\
\text { й зовнішніми умовами; самостійне й усвідомлене } \\
\text { узгодження } \\
\begin{array}{l}\text { особливостей особистості із змістом і вимогами } \\
\text { професійної діяльності» }\end{array}\end{array}$ \\
\hline 7. & $\begin{array}{l}\text { Г. О. Корсун } \\
\text { [13] }\end{array}$ & $\begin{array}{l}\text { «складне структурне } \\
\text { взаємопов'язаних і повдунаних переконаннями } \\
\text { морально-вольових якостей особистості, способів } \\
\text { поведінки, знань про професії, практичні вміння і } \\
\text { навички, сформовані у відповідності } 3 \text { вимогами } \\
\text { суспільства й можливостями навчально-виховного } \\
\text { процесу в школі» }\end{array}$ \\
\hline
\end{tabular}

Згідно Закону України «Про військовий обов'язок і військову службу» «Військова служба є державною службою особливого характеру, яка полягає у професійній діяльності придатних до неї за 
станом здоров'я і віком громадян України, іноземців та осіб без громадянства, пов'язаній із обороною України, іiі незалежності та територіальної цілісності» [18, ст. 2]. «На військову службу за контрактом приймаються громадяни, які пройшли професійнопсихологічний відбір...» [18, ст. 20]. Отже основними вимогами професії $\epsilon$ придатність за станом здоров'я та позитивний психологічний стан особистості. Що стосується розгорнутого в часі процесом самостійного узгодження досягнутих але ще не реалізованих особистістю можливостей і вимог до військової служби за контрактом (до службо-бойової діяльності), то тут доцільно розглянути запропоновану М. М. Медвідь структурну модель стимулювання до службово-бойової діяльності через системи професійної орієнтації, підготовки та освіти [1, с. 23].

Період 1 структурної моделі - отримання інформації про можливість проходження військової служби та початкових професійних знань. Суб’єктами профорієнтаційної роботи є загальноосвітні школи та коледжі, військові ліцеї.

Період 2 структурної моделі - початок військової служби за контрактом на посаді солдата. Вимогами до особистості, яка бажає перейти у цей період, існують лише по відношенню до іiі стану здоров'я та до психологічного стану. Для того щоб особистість могла залишитись у цьому періоді або перейти у інший - вимоги до неї зростають, що проявляються у рівні сформованих компетентностей для виконання службово-бойових завдань.

Отже, професійне самовизначення старшокласника щодо проходження військової служби за контрактом є розгорнутим в часі процесом самостійного узгодження досягнутих але щее не реалізованих ним можливостей $i$ вимог проходження військової служби за контрактом щодо стану здоров'я та психологічного стану.

Висновки. За результатами проведеного дослідження виявлено існування практичної проблеми дослідження, яка проявляється у зміні способу комплектування військових формувань 3 призовного на контрактний, що призводить до зникнення найбільш значущих умов формування у громадян України готовності до проходження військової служби за контрактом. Відповідно виявлено існування науковопедагогічної проблеми професійного самовизначення старшокласників щодо проходження військової служби за контрактом, яка проявляється у відсутності досліджень присвячених вирішенню практичної проблеми шляхом сумісного виконання завдань загальноосвітніх шкіл щодо сформованості у їхніх випускників готовності до вибору професії та військових формувань щодо зміни їх способу комплектування на контрактний. Розкрито сутність поняття 


\section{Збірник наукових статей}

«професійне самовизначення старшокласника щодо проходження військової служби за контрактом».

\section{Література}

1. Медвідь М. М. Методологія формування і розвитку людських ресурсів для використання у службово-бойовій діяльності: автореф. дис... докт. екон. наук : 08.00.07 / М. М. Медвідь; Харківський нац. екон. ун-т ім. Семена Кузнеця. - Х., 2015. - 40 с.

2. Пащенко О. Ю. Підготовка старшокласників до вибору майбутньої професії працівника міліції: Автореф. дис... канд. пед. наук: 13.00.07 / О. Ю. Пащенко; Терноп. держ. пед. ун-т ім. Володимира Гнатюка. - Т., 2000. - 18 с.

3. Мачуський В. В. Формування готовності старшокласників до професійного самовизначення у сфері технічної діяльності в позашкільних закладах: Автореф. дис... канд. пед. наук: 13.00.07 / В. В. Мачуський; Ін-т пробл. вихов. АПН України. - К., 2001. - 16 с.

4. Піддячий М. I. Організаційно-педагогічні умови підготовки старшокласників до професійного самовизначення у міжшкільних навчально-виробничих комбінатах: Автореф. дис... канд. пед. наук: 13.00.07 / М.І.Піддячий; Ін-т пробл.вихов.АПН України.-К.,2002.-19 с.

5. Мельник О. В. Підготовка старшокласників до самостійного вибору майбутньої професії в процесі профільного трудового навчання: Автореф. дис... канд. пед. наук: 13.00.07 / О. В. Мельник; Інт пробл. виховання АПН України. - К., 2003. - 20 с.

6. Капустіна О. В. Педагогічні умови активізації професійного самовизначення старшокласників у навчально-виховній діяльності школи: Автореф. дис... канд. пед. наук: 13.00.07 / О. В. Капустіна; Ін-т проблем виховання АПН України. - К., 2004. - 20 с.

7. Туляєв В. В. Організаційно-педагогічні умови підготовки старшокласників до професійного самовизначення у спеціалізованих загальноосвітніх навчальних закладах художнього профілю: автореф. дис... канд. пед. наук: 13.00 .07 / В. В. Туляєв; Ін-т пробл. виховання АПН України. - К., 2008. - 18 с.

8. Назарчук А. А. Педагогічні умови формування у старшокласників готовності до вибору професії офіцераприкордонника: автореф. дис... канд. пед. наук: 13.00.07 / А. А. Назарчук; Ін-т пробл. виховання АПН України. - К., 2009. - 20 с.

9. Шабдінов М. Л. Формування професійного самовизначення старшокласників у процесі технологічної підготовки: автореф. дис... канд. пед. наук : 13.00 .07 / М. Л. Шабдінов; Ін-т пробл. виховання НАПН України. - К., 2010. - 20 с.

10. Закатков Д. О. Технології підготовки учнівської молоді до професійного самовизначення: монографія / Д. О. Закатков/ - К. : Педагогічна думка, 2012. - 160 с. 
11. Професійне самовизначення учнівської молоді в умовах освітнього округу : монографія / Л. А. Гуцан, О. Л. Морін, 3. В. Охріменко, О. М. Пархоменко, Л. І. Гриценок; І. І. Ткачук, за ред. О. Л. Моріна. - Харків : «Друкарня Мадрид». -220 с.

12. Вітковська О. I. Психологічні умови професійного самовизначення випускників середніх шкіл у процесі профконсультації: Автореф. дис... канд. психол. наук: 19.00.07 / О. І. Вітковська; Інститут педагогіки і психології професійної освіти АПН України. - К., 2002. - 22 с.

13. Корсун Г. О.Професійне самовизначення старшокласників як проблема теорії та методики виховання в роботах вітчизняних та зарубіжних вчених / Г. О. Корсун // Вісник Національного технічного університету України “Київський політехнічний інститут". Філософія. Психологія. Педагогіка. - 2007 рік, Номер 2, Частина 1. - Режим доступу: http://novyn.kpi.ua/2007-2-1/06_Korsun.pdf.

14. Сошенко С. М. Професійно орієнтована освітня діяльність у процесі довузівської підготовки абітурієнтів: Автореф. дис... канд. пед. наук: 13.00 .04 / С. М. Сошенко; Харківський національний педагогічний університет імені Г. С. Сковороди. - Х., 2011. - 23 с.

15. Економічна енциклопедія: у трьох томах. - Т. 3 / Редкол.: С. В. Мочерний та ін. - Київ : вид. центр «Академія», 2002. - 952 с.

16. Джура О. Д. Освіта в системі факторів професійного самовизначення особистості: Автореф. дис... канд. філос. наук: 09.00.03 / О. Д. Джура; Ін-т вищої освіти АПН України. -К., 2004.-21 с.

17. Про Основні орієнтири виховання учнів 1-11 класів загальноосвітніх навчальних закладів України : наказ Міністерства освіти і науки, молоді та спорту України від 31.10.2011p. -№1243.-97с.

18. Про військовий обов'язок і військову службу [Електронний pecypc] : Закон України від 25.03.1992 p. № 2232-XII. - Режим доступу : http://zakon4.rada.gov.ua/laws/show/2232-12.

\section{Владимир Демьянишин, Юлия Медвидь. Профессиональное самоопределение гражданина Украины относительно прохождения военной службы по контракту как научно- педагогическая проблема.}

Обнаружено существование практической проблемы исследования, которая проявляется в изменении способа комплектования воинских формирований с призывного на контрактный, что приводит $к$ исчезновению наиболее значимых условий формирования у граждан Украины готовности к прохождению военной службы по контракту. Обнаружено существование научно-педагогической проблемы профессионального самоопределения старшеклассников относительно прохождении военной службы по контракту, которая 
проявляется в отсутствии исследований посвященных решению практической проблемы путем совместного выполнения задач общеобразовательных икол по сформированности у их выпускников готовности $к$ выбору профессии и воинских формирований по изменению их способа комплектования на контрактный. Раскрыта сущуность понятия «профессиональное самоопределение стариеклассника относительно прохождения военной службы по контракту» под которым предложено понимать развернутый во времени процесс самостоятельного согласования достигнутых но еще не реализованных им возможностей и требований прохождения военной службы по контракту относительно состояния здоровья $и$ психологического состояния.

Ключевые слова: профессиональное самоопределение, военная служба по контракту.

Volodymyr Demianyshyn, Yuliia Medvid. Professional selfdetermination of the citizens of Ukraine conducting the military service under contract as a scientific-pedagogical problem.

The existence of a practical problem of research, which manifests itself in changing the way of recruiting military formations from contract to contract, is revealed. These changes lead to the disappearance of the most significant conditions for the formation of readiness for the military service under contract among Ukrainian citizens. The existence of a scientific and pedagogical problem of professional self-determination of senior pupils regarding the conducting the military service under contract is revealed. The problem manifests itself in the absence of researches on solving a practical problem. The best way solve it is through the joint implementation of tasks of secondary schools to form of their graduates willingness to choose a profession and military units to change their ways of manning.The essence of the concept of "professional self-determination of senior pupils to conduct the military service under the contract» is proposed. It is proposed to understand the process of independent development in time that is self-consistent with the achieved but not yet implemented opportunities and requirements for military service under contract regarding health status and psychological state.

Keywords: professional self-determination, military service under contract.

Стаття надійшла до редакційної колегії 31.10.2017

\section{Інформація про авторів:}

Дем'янишин Володимир Миколайович - старший викладач, Національна академія Національної гвардії України.

Медвідь Юлія Іванівна - науковий співробітник науковоорганізаційного відділу, Національна академія Національної гвардії України. 